\title{
Sjávarútvegur og fiskveiðistjórnun: um hvað snúast lög um stjórn fiskveiða?
}

\author{
Lúðvík Elíasson²
}

\begin{abstract}
Ágrip
Undanfarin misseri hafa komið fram nokkur frumvörp til laga um stjórn fiskveiða. Pessi frumvörp eiga pað öll sammerkt að í orði kveðnu snúast pau um fiskveiðistjórnun. Pegar betur er að gáð eiga pau pað pó flest sameiginlegt með gildandi lögum um stjórn fiskveiða að taka aðeins að hluta til á peim markaðsbrestum sem fylgja nýtingu auðlinda sjávar en samhliða er reynt að leysa fjölda annarra ótengdra mála með reglum um fiskveiðar. Hér verður farið yfir helstu markaðsbresti sem fylgja fiskveiðum og rýnt í hvernig tekið er á peim í gildandi lögum og nýjasta frumvarpi til laga um fiskveiðistjórnun. Pá eru ýmis ákvæði laganna er lúta að tekjudreifingu og byggðamálum skoðuð og pví velt upp hvort ekki megi ná markmiðum peirra á skilvirkari hátt en með kvöðum á sjávarútveg.
\end{abstract}

\begin{abstract}
Although it is stated in the several fisheries management bills which have recently been discussed in parliament, that they are concerned with the management of fisheries they do, however, as does the current fisheries management legislation, only partially address the market failures associated with fisheries while revolving around a number of unrelated issues. This article discusses the market failures associated with open access fisheries and looks at how they are addressed by the current legislation as well as in the most recently proposed general revision put forth by the government. Parts of the legislation concern the distribution of income and the distribution of the population. It is contemplated whether these goals are perhaps more appropriatley achieved by other means than constraints on fisheries.
\end{abstract}

JEL flokkun: K11, Q22, Q28

Lykil hugtök: Eignarréttur, endurnýjanlegar auðlindir, fiskveiðar, framseljanlegir kvótar, fiskveiðistjórnun

\footnotetext{
${ }^{1}$ Byggt á erindi sem flutt var á ráðstefnu Tímarits um viðskipti og efnahagsmál um fiskveiðistjórnun 9. maí 2012.

${ }^{2}$ Höfundur er hagfræðingur hjá Seðlabanka Íslands. Pær skoðanir sem hér koma fram eru höfundar og purfa ekki að fara saman við skoðanir Seðlabankans.
} 


\section{Inngangur}

Раð er óumdeilt að sjávarútvegur er mikilvæg grein á Íslandi. Á bilinu 1,0\% til 2,5\% heimsaflans hefur veiðst við Ísland á ári hverju á síðustu 60 árum. ${ }^{3}$ Hlutdeild veiða við Ísland hefur pó dregist nokkuð saman pað sem af er pessari öld á meðan ákveðin stöðnun hefur orðið í heimsaflanum (mynd 1). Samsetning afla á Íslandsmiðum hefur sveiflast nokkuð á pessum tíma. Botnfiskur, par á meðal porskur, ýsa, ufsi og karfi, hefur verið uppistaðan í verðmæti íslenskra sjávarafurða. Veiði pessara tegunda jókst á fyrri hluta tímabilsins og fór úr 270 púsund tonnum árið 1946 í 670 púsund tonn 1981 (mynd 2). Frá peim tíma hefur botnfiskaflinn dregist saman á ný og var um 340 púsund tonn árið 2011. Verðmæti uppsjávaraflans hefur jafnan verið minna en botnfiskaflans en uppsjávaraflinn hefur verið mun sveiflukenndari og með tímanum hefur orðið nokkur breyting á pví hvaða tegundir eru uppistaða hans hverju sinni. Heildaraflinn óx úr um pað bil 370 púsund tonnum árið 1945 og náði hámarki í 2,2 milljónum tonna 1997. Heildaraflinn sveiflast töluvert milli ára, oftast vegna pess að veiðar á tiltekinni tegund uppsjávarafla aukast hröðum skrefum í nokkur ár og hrynja síðan verulega. Petta á við um aflabrestinn sem varð í síldveiðum 1968 og 1969 og hrunið í loðnuveiðum 1982, 1991 og 2006 til 2010. Mikið getur áunnist ef hægt er að draga úr slíkum sveiflum og minnka líkurnar á hruni stofna með skynsamlegri fiskveiðistjórnun.

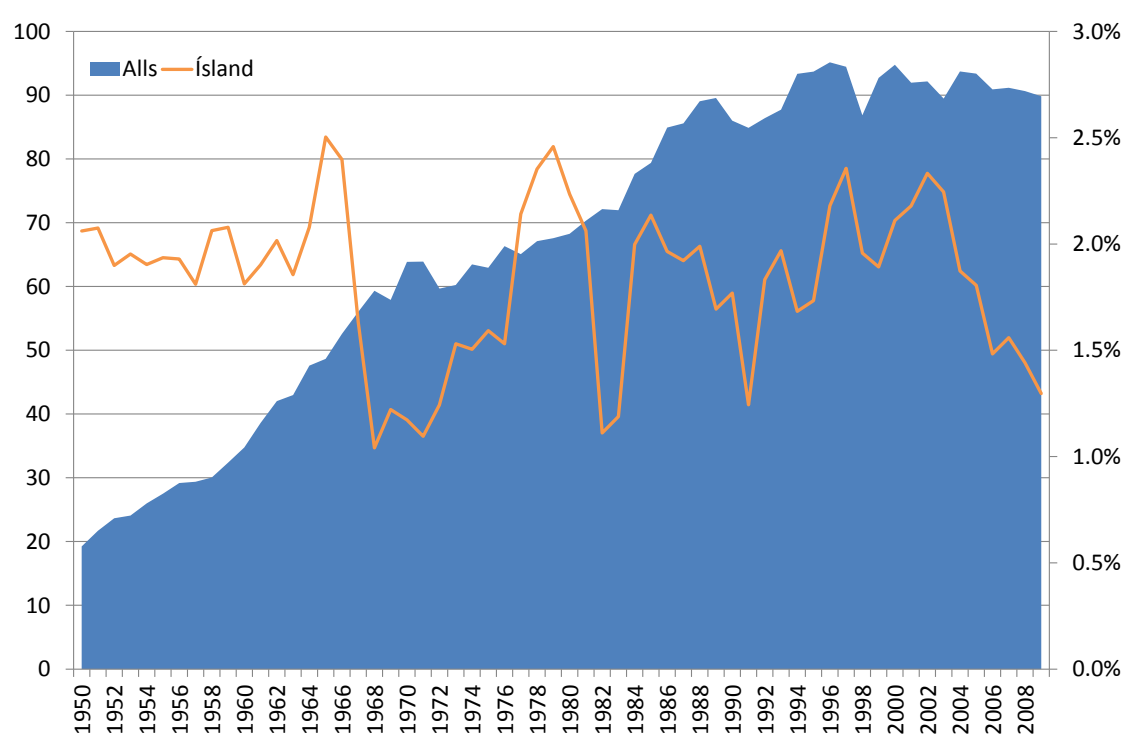

Mynd 1. Próun heimsafla frá 1950 til 2009 og hlutdeild Íslands. Skyggða svæðið sýnir heimsafla í milljónum tonna (vinstri ás). Línan sýnir hlutdeild veiða á Íslandsmiðum í heimsafla (hægri ás). Heimild: Hagstofa Íslands.

\footnotetext{
3 Á Íslandi búa um 0,004\% íbúa heimsins.
} 


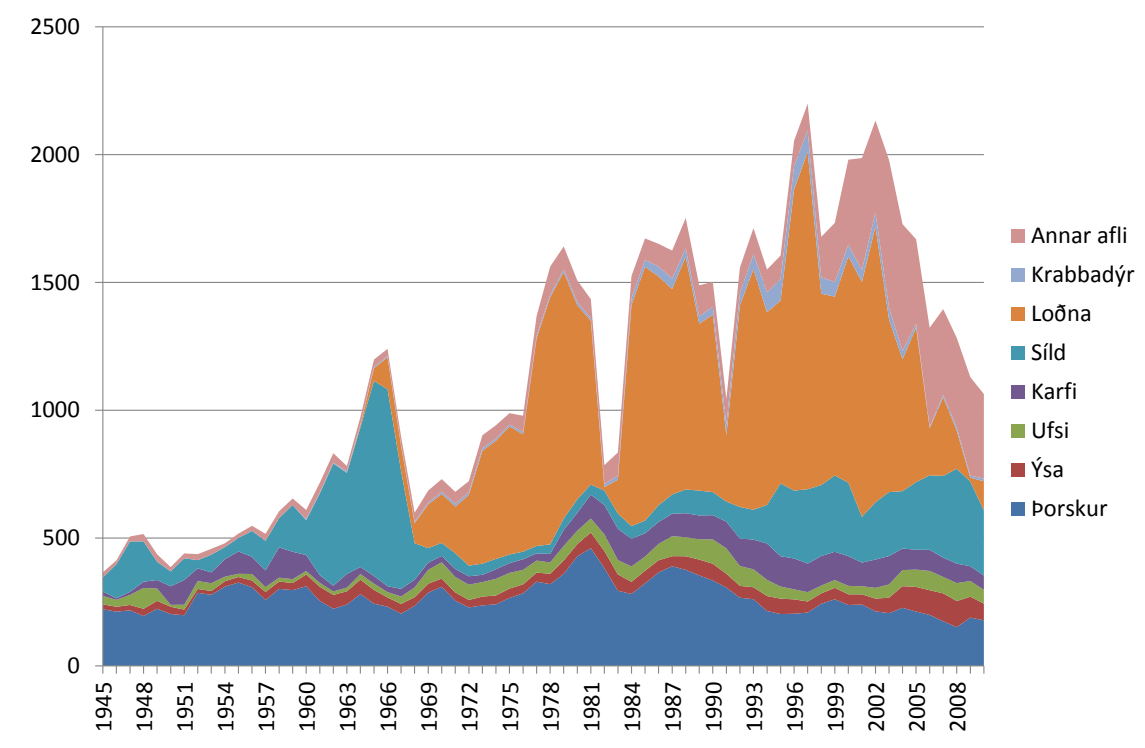

Mynd 2. Afli íslenskra fiskiskipa eftir tegundum, púsundir tonna. Heimild: Hagstofa Íslands.

Vægi sjávarútvegs sem atvinnugreinar óx verulega á nítjándu öldinni. Við upphaf hennar starfaði um 6\% vinnuaflsins við sjávarútveg en um aldamótin 1900 var pað hlutfall komið í 17,5\% (mynd 3). Fyrstu prjá áratugi síðustu aldar starfaði um fimmti hver vinnandi maður við fiskveiðar og fiskvinnslu en síðan hefur hlutfall starfandi í sjávarútvegi dregist saman. Pað fór niður í 4\% árið 2008 en hefur aðeins risið á ný síðan pá og var orðið 5,3\% 2011.

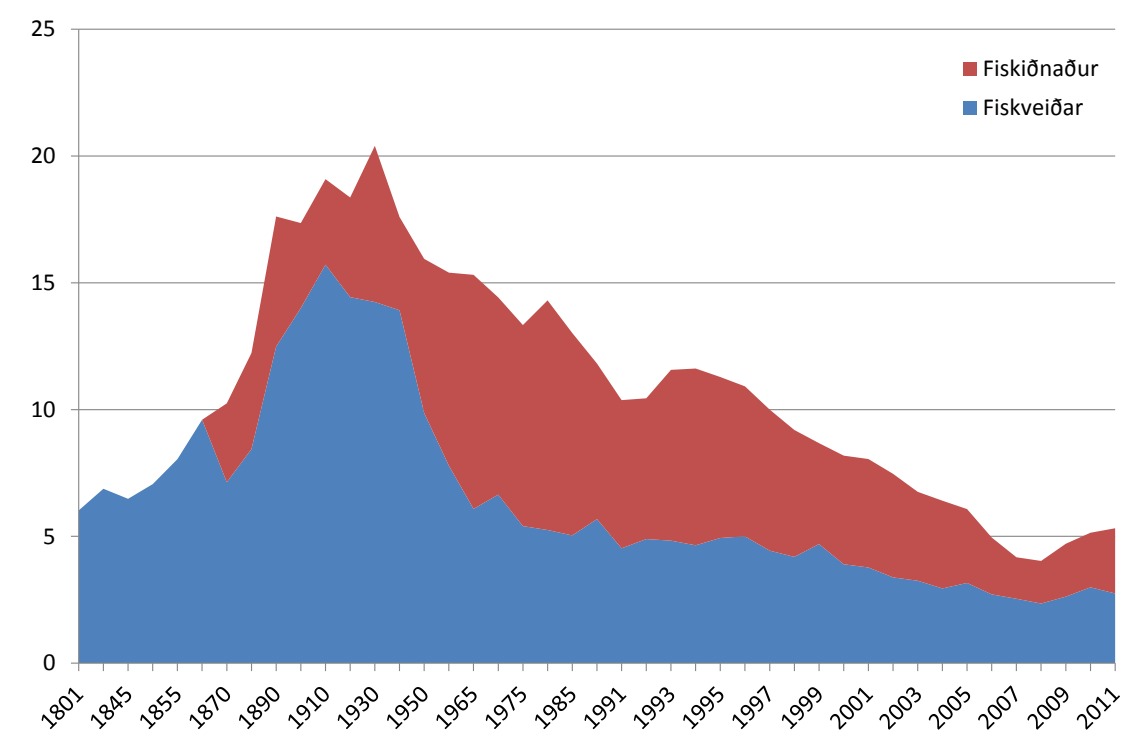

Mynd 3. Hlutur vinnuaflsins (prósentur) sem starfar við fiskveiðar og fiskiðnað. Heimild: Hagstofa Íslands.

Mikið var fjárfest í sjávarútvegi á síðustu öld og frá 1945 til 1965 var að jafnaði um 8,7\% fjármunastofnsins bundinn í sjávarútvegi (mynd 4). Par af um 4,5\% í fiskveiðum og um 4,3\% í fiskvinnslu. Heildarhlutfall fjármunastofnsins í sjávarútvegi hélst nokkuð stöðugt í kringum 7,7\% næstu prjá áratugina og fór fyrst niður fyrir 7\% árið 1998 pegar stóriðjufjárfestingar jukust. Innbyrðis hlutfallið breyttist pó mjög og síðustu tvo áratugina 
hefur aðeins um fjórðungur fjármunastofns í sjávarútvegi verið í fiskvinnslu en prír fjórðu í fiskveiðum.

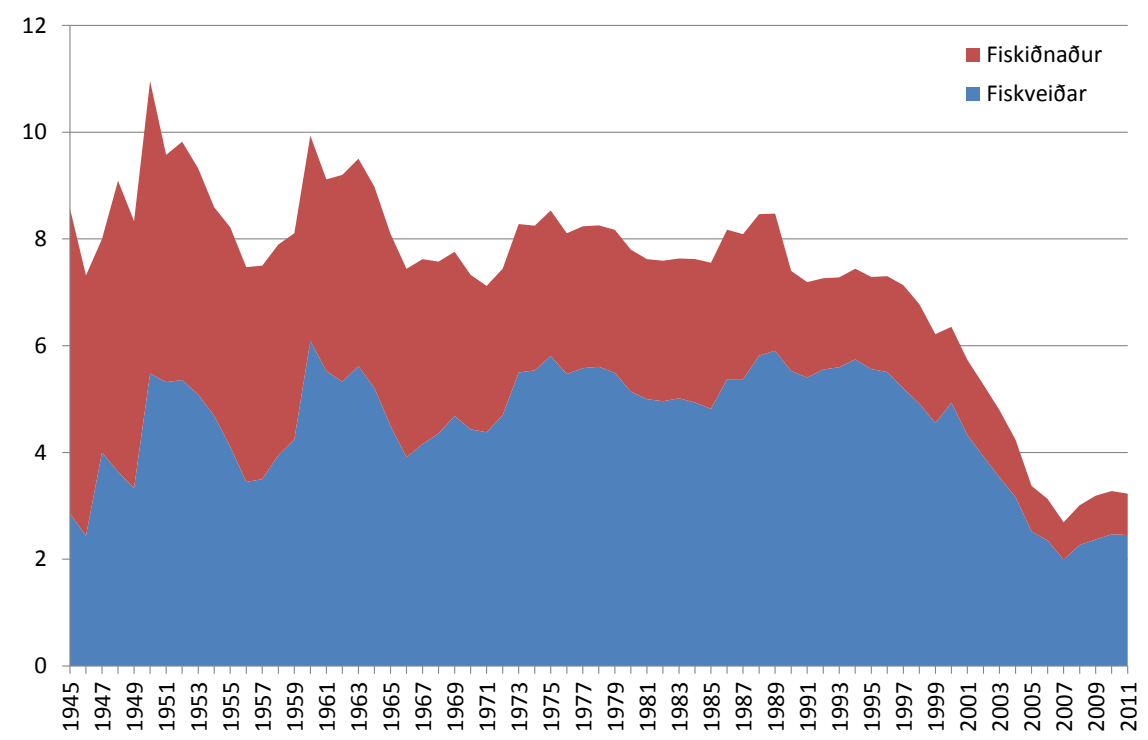

Mynd 4. Hlutur fjármunastofnsins (prósentur) sem er notaður er við fiskveiðar (í sjávarútvegi) og í fiskiðnaði (við vinnslu sjávarafurða). Heimild: Hagstofa Íslands.

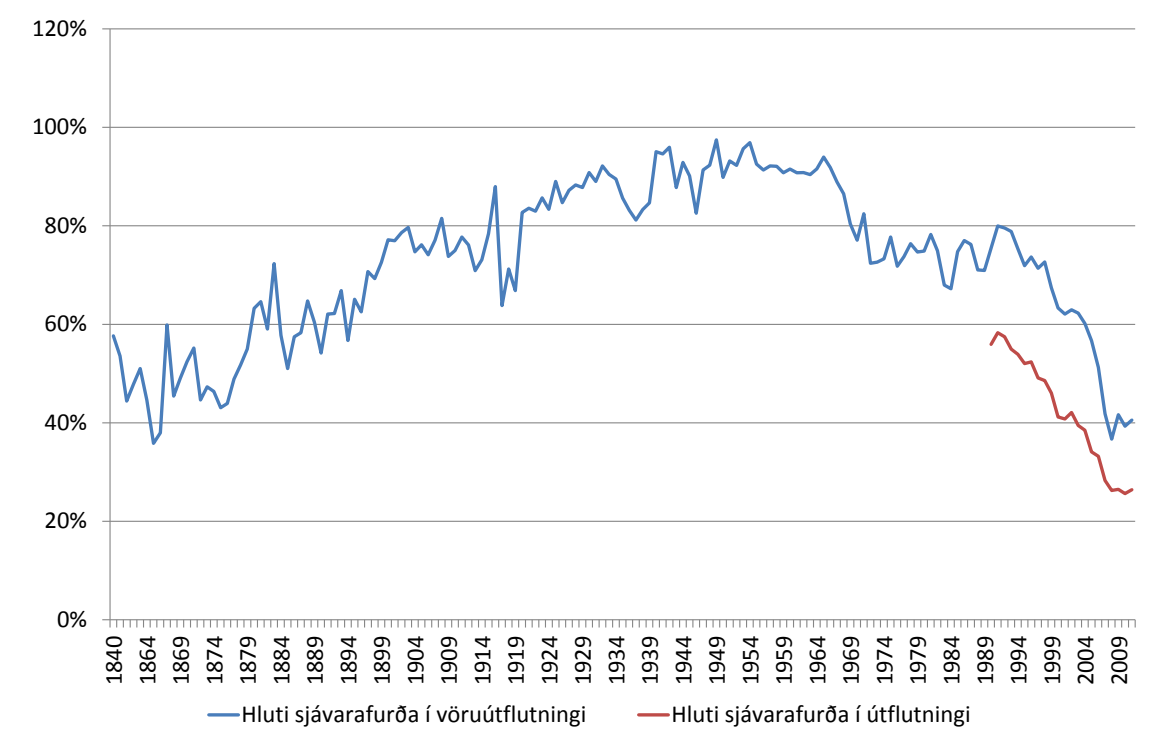

Mynd 5. Hlutur sjávarafurða í útfluttum vörum og útflutningi (vöru og pjónustu). Heimild: Hagstofa Íslands.

Sjávarútvegur hefur lengi vegið pyngst einstakra greina í útflutningi en pað hefur breyst á allra seinustu árum. Hlutdeild sjávarafurða í vöruútflutningi féll niður í 42\% árið 2007 og var pað í fyrsta skipti í 130 ár sem pað var undir helmingi (mynd 5). Hæst fór hlutdeild sjávarútvegs í útfluttum vörum í 97\% um miðja síðustu öld. Útflutningur áls hefur farið fram úr sjávarafurðum frá 2007 og hefur hlutur sjávarútvegs í útflutningi vara og pjónustu haldist í rúmum fjórðungi seinustu 5 árin. 
Hagstofa Íslands hefur birt framleiðsluuppgjör pjóðhagsreikninga fyrir árin 1997 til 2011. Hlutdeild sjávarútvegs í vergri landsframleiðslu var samkvæmt pví um 13\% árið 1997 en féll niður undir 6\% 2007 (mynd 6). Síðan pá hefur hlutdeild sjávarútvegs vaxið á ný og var 11\% $2011 .^{4}$

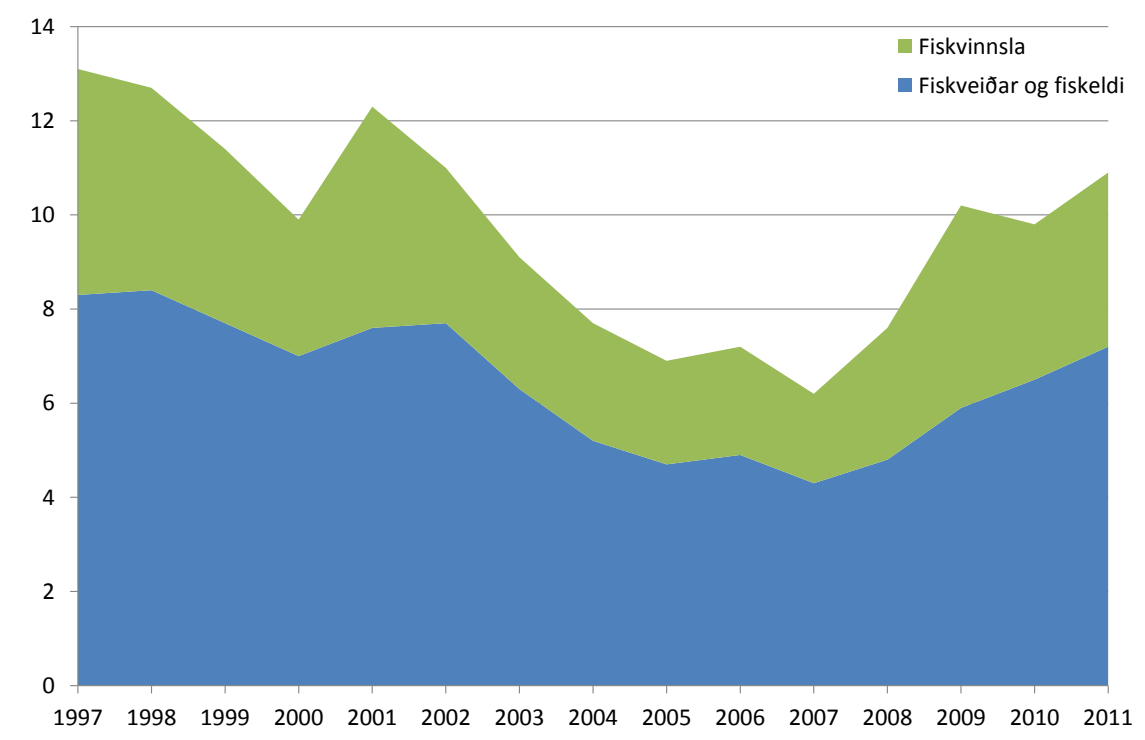

Mynd 6. Hlutdeild fiskveiða og fiskvinnslu í vergri landsframleiðslu (prósentur). Heimild: Hagstofa Íslands.

Hvernig sem á pað er litið er ljóst að sjávarútvegur er afar mikilvæg atvinnugrein á Íslandi. Pótt hlutfall vinnuaflsins og fjármunastofnsins sem er bundið í greininni fari minnkandi eru pað samt sem áđur fjölmörg störf og mikil fjárfesting. Og páttur sjávarútvegs í útflutningstekjum pjóðarinnar er enn mikill og hefur heldur aukist seinustu árin. •að er pví kappsmál landsmanna allra að greinin sé rekin á hagkvæman og sjálfbæran hátt.

\section{Sérstaða endurnýjanlegra auðlinda}

Náttúruauðlindir almennt, og endurnýjanlegar auðlindir sérstaklega, eru erfiðar viðfangs vegna samspils illa skilgreinds eignarréttar, ytri áhrifa og markaðsbresta. ${ }^{5}$ Orsakir pessara vandamála geta verið fjölbreyttar og par á meðal má nefna: frjálsan aðgang að auðlind með illa skilgreindan eignarrétt, að horft er fram hjá pví að auðlindastofn er sambærilegur við fjármunastofn par sem taka verður tillit til aukningar og rýrnunar (fjárfestingar og afskrifta), stofnarnir eru lifandi og ferðast um, og erfitt er að taka tillit til flókins samspils auðlindastofna í náttúrunni, verðmætis sem stafar af ýmsu öðru en beinni nýtingu auk pess

\footnotetext{
${ }^{4}$ Pví er oft haldið fram að í reynd sé mikilvægi greinarinnar mun meira en pessar tölur benda til par sem ýmis starfsemi önnur tengist pjónustu við sjávarútveg. Sjá Hagfræðistofnun (2007).

${ }^{5}$ Brown (2000) gefur ágætt yfirlit yfir pau vandamál sem einkenna endurnýjanlegar náttúruauðlindir og reynsluna af peim leiðum sem reyndar hafa verið til að stýra nýtingu peirra. Umfjöllunin hér byggist að nokkru á peirri grein.
} 
sem erfitt getur reynst að ná samkomulagi um nýtingu stofna sem ferðast um yfirráðasvæði fleiri en einnar pjóðar.

Pegar margir einstaklingar keppast um nýtingu á auðlind en enginn peirra hefur eða getur framfylgt eignarrétti yfir auðlindinni skapast ofnýting sem rekja má til pess að aðgangur er frjáls en eignarréttur ófullkominn (Hardin (1968)). Um er að ræða ytri áhrif par sem nýting eins hefur áhrif á möguleika annars til að nýta auðlindina. Vegna ytri áhrifa endurspeglar markaðsverð ekki verðmæti ónýttrar auðlindar og pess vegna munu ákvarðanir einstakra notenda um nýtingu hennar ekki leiða til niðurstöðu sem er hagkvæm fyrir heildina (Brown (2000)).

Auðlindastofn er að mörgu leyti sambærilegur við fjármunastofn. Hann stækkar ef meira bætist við en af er tekið. Stofnstærðin getur haft áhrif á vaxtarhraðann, bæði á nýliðun og dánartíðni. Stofn á ákveðnu svæði getur einnig stækkað eða minnkað vegna flutninga til og frá svæðinu. Lifandi auðlindir ferðast um og pess vegna getur verið erfitt að koma á pær böndum eignarréttar. Ef verið er að hámarka arðsemi fiskistofna parf að taka tillit til pess hver ávöxtun viðbótarafla sem veiddur er væri ef hann væri látinn bíða lengur. Auðlindastofnar eru pó frábrugðnir fjármunastofnum að pví leyti að ef auðlindastofninn klárast verður ekki aftur snúið.

Pessu til viðbótar er erfitt að taka fullt tillit til alls ábata sem ekki hefur beint með nýtingu auðlindar að gera. Sem dæmi má taka verndun náttúruundra og heimkynna dýrategunda í útrýmingarhættu. Petta eru dæmi um verðmæti sem ráðast hvorki á markaði né vegna notkunar. Við mat á slíkum verðmætum er tilvist peirra í framtíð jafnan gert hærra undir höfði en við hefðbundna núvirðingu.

Erfiðleikar við að koma á eignarrétti á náttúruauðlindum eru ein helsta orsök ytri áhrifa og valda pví að mikill munur getur verið á virði og fórnarkostnaði. Erfitt er að skapa skilvirka markaði fyrir náttúrauðlindir og afurðir peirra af ýmsum ástæðum. Par má nefna ytri áhrif vegna lögsögumarka, almannagæði og virði án notkunar (svo sem tilvistarvirði), almannagæði par sem njótendur og peir sem bera kostnað eru ekki á sama stað, flókið samspil auðlindarinnar við vistkerfið sem gerir tengsl ábata og kostnaðar óljós, og að mjög langur tími getur liðið milli aðgerða peirra einstaklinga sem eru að nýta auðlind og peirra áhrifa sem pær hafa á samfélagið. Pessu til viðbótar getur opinber stefna um auðlindanýtingu leitt til óvæntra áhrifa á umhverfið. Að auki eru endurnýjanlegar auðlindir alræmdar fyrir virðingarleysi fyrir lögsögumörkum og stofnarnir teygja sig yfir og ferðast hiklaust yfir landamæri (Brown (2000, bls. 10)). Pví er ekki aðeins erfitt að skilgreina og innleiða eignarétt heldur getur jafnframt verið mjög erfitt fyrir hið opinbera að hafa afskipti af auðlindanotkun og lausn pessa vanda kallar oft á samvinnu fjölda ríkja. Hér nægir að nefna nýlegt dæmi af ferðalagi markíls í Norður-Atlantshafi. 


\section{Tilraunir til að stýra fiskveiðum}

Pegar menn áttuðu sig á pví pegar nokkuð var liðið á seinustu öld að frjáls aðgangur að endurnýjanlegum auðlindum getur leitt til ofveiði voru fyrstu viðbrögðin að draga úr heildarafla (Schaefer (1954)). Heildarkvótar voru ákveðnir og veiðar bannaðar pegar peir náðust. Mikil sóun átti sér stað pegar útgerðir kepptust um að hámarka eigin hlutdeild í heildarkvótanum. Раð var ekki fyrr en upp úr miðri síðustu öld að farið var að taka tillit til pess að auðlindir eru fjármunastofn og verð á aflaeiningu er rétta stjórntækið (Gordon (1954)). Áður höfðu hagfræðingar stungið upp á pví að draga úr sókn með pví að takmarka framleiðslupætti og pað hægði aðeins á á meðan fundnar voru leiðir til að nýta aðra framleiðslupætti sem ekki voru takmarkaðir. Pví næst var stungið upp á gjaldtöku en pað fékk engan hljómgrunn utan hagfræðingastéttarinnar.

Einföld hagfræðilíkön af fiskveiðum og fiskveiðistjórnun draga pað fram að par sem veiðimenn keppa hver við annan við veiðar úr sama stofninum, p.e. eignarhaldið á auðlindinni er ófullkomið, pá reyna peir að hámarka skammtíma hagnað. Peir taka ekki tillit til áhrifa breytinga á stofnstærð á vöxt stofnsins. Með öðrum orðum er gert ráð fyrir pví að óveiddur fiskur sé verðlaus og kostnaður við veiðarnar pví vanmetinn (Conrad og Clark (1987, kafli 2)). Pess vegna verður sókn í fiskistofna alltaf of mikil í samkeppni með frjálsan aðgang. Ef allir veiðimenn gætu unnið sameiginlega að pví að hámarka verðmæti aflans myndu peir taka tillit til pess að vöxtur stofnsins er háður stofnstærðinni. Ef á að ná fram hagkvæmri nýtingu fiskistofna með skattlagningu á afla pyrfti skatturinn að vera jafn jaðarvirði stofnsins (Conrad og Clark (1987, bls. 94)). Til að finna réttan skatt pyrfti mikla vitneskju og mikið eftirlit til að leggja hann á og framfylgja. Auk pess sem skatturinn væri breytilegur yfir tíma. Reyndin hefur verið að par sem skattlagningu afla er beitt er hún jafnan smávægileg í samanburði við pað sem pyrfti til að ná fram hagkvæmri nýtingu. Skattlagning miðast oftast við önnur markmið en hagkvæmni veiðanna, svo sem að fjármagna kostnað við eftirlit (Conrad og Clark (1987)). Í nýlegum lögum um veiðigjöld (Lög nr. 74/2012) segir til dæmis: „Veiðigjöld eru lögð á í peim tilgangi að mæta kostnaði ríkisins við rannsóknir, stjórn, eftirlit og umsjón með fiskveiðum og fiskvinnslu og til að tryggja pjóðinni hlutdeild í peim arði sem nýting sjávarauðlinda skapar." Samkvæmt lögum er pví tilgangur veiðigjaldsins annar en að stuðla að hagkvæmri nýtingu fiskistofna.

Notkun á verðlagningu sem stýritæki kallar á vitneskju um jaðarkostnaðinn og hvernig hann er að próast. Lög og reglur sem hefta veiðar eru oftast innleidd í kjölfar ofveiði, p.e. pegar afkoma útgerða er með versta móti. Рað er óheppilegur tími fyrir stjórnmálamenn til að ípyngja útgerðum enn frekar með pví að innleiða gjaldtöku og kann pað að skýra skort á vinsældum markaðsmiðaðra lausna á auðlindavandanum.

Í stað pess að leggja skatt á afla er hægt að draga úr sókn. Víða hefur verið reynt að draga úr sókn með pví að fækka leyfðum veiðidögum. Pá skapast keppni um að ná sem mestum afla á peim tíma sem veiðar standa yfir. Afleiðingar eru sóun sem meðal annars kemur fram í offjárfestingu í veiðum (Homans og Wilen (1997)). Hægt er að hafa áhrif á sókn með pví að 
rukka gjald fyrir leyfi til pess að veiða og pá er reynt að stilla pað af pannig að landað verði æskilegu magni. Ef rukkað er á pennan hátt fyrir réttinn til að veiða pá rennur ábatinn af fiskveiðunum allur til pess aðila sem útdeilir réttindunum (Conrad og Clark (1987)).

Раð fiskveiðistjórnunarkerfi sem hefur haft mest fylgi meðal hagfræðinga undanfarna áratugi er kerfi framseljanlegra kvótahlutdeilda. ${ }^{6}$ Sú leið býr til eignarrétt par sem kvótahlutdeild er heimild til ráđstöfunar á tiltekinni prósentu af heildaraflaheimild tímabilsins í tiltekinni tegund. Handhafi hverrar kvótahlutdeildar hefur ráðstöfunarrétt yfir henni. Hann hefur heimild til að veiða sem kvótahlutdeildinni nemur eða hann getur selt hana eða leigt. Framsalið er lykilforsenda sem tryggir að veiðarnar verða hagkvæmar. Peir sem veiða með minnstum kostnaði hafa hvata til að greiða hæsta verðið fyrir viðbótar kvótahlutdeild. Peir sem veiða með mestum kostnaði hafa pví hag af pví að selja frá sér kvótahlutdeild. Innleiðing framseljanlegra aflahlutdeilda höfðar frekar til veiðimanna en gjaldtaka, svo fremi sem hlutdeildunum er ekki útdeilt upphaflega með uppboði á frjálsum markaði.

Ríkið getur skapað eignarrétt og útdeilt eignum til útgerðarmanna par sem kveðið er á um rétt til veiða á tilteknu magni og gæðum á tilgreindu tímabili. Leyfður afli breytist milli tímabila að teknu tilliti til aðstæðna og óvissu pannig að hvert leyfi getur verið tilgreind hlutdeild í heildarafla. Virði framseljanlegrar aflahlutdeildar samsvarar einingaverði eða leigugjaldi. Virði auðlindarinnar eykst vegna pess að kerfið dregur úr kostnaði. Með tilliti til hámörkunar á arðsemi af veiðunum skiptir ekki máli hvort aflahlutdeildirnar eru leigðar út á hverju tímabili, seldar með uppboðsfyrirkomulagi eða afhentar á annan hátt, til dæmis út frá veiðireynslu. Aðalatriðið er að pær séu framseljanlegar og viðskipti með pær frjáls. Úthlutunin hefur aftur á móti áhrif á pað hver hefur aðgang að arðinum í greininni og um pað má alltaf finna ólíkar skoðanir hvort heppilegast sé að arðurinn sé til ráðstöfunar hjá peim sem stunda veiðarnar, fjármagna pær, hinu opinbera og peim stjórnmálamönnum sem pví stýra hverju sinni eða hjá almenningi í landinu. Pessu má stilla upp á ýmsan hátt og skipta arðinum á milli pessara aðila án pess að pað komi niður á arðsemi í greininni. En pað er líka hægt að draga verulega úr arðseminni ef skipting arðsins verður meginmarkmið fiskveiðistjórnunarkerfisins og ekki verður hugað að hagkvæmni pess. Раð er pví afar mikilvægt að gefa ekki ranga hvata til dæmis með pví að takmarka viðskipti með aflahlutdeildir.

Pótt framseljanlegar kvótahlutdeildir leysi ýmis vandamál tengd nýtingu endurnýjanlegra náttúruauðlinda pá er fjarri pví að pær leysi öll vandamál. Hvati til pess að hámarka virði kvótahlutdeildar með pví að velja fiska og fleygja undirmálsafla eykst ef eftirlit er ófullnægjandi (Anderson (1994), Árnason (1994)). Meðafli er einnig alltaf vandamál p.e. ef verið er að veiða eina tegund pá er hluti aflans af öðrum tegundum (Davies, Cripps, Nickson og Porter (2009)). Hvatinn til að fleygja pví sem aflast af örðum tegundum getur jafnvel

\footnotetext{
${ }^{6}$ Sjá Brown (2000) og tilvísanir par.
} 
aukist ef ekki eru virkir leigumarkaðir fyrir viðkomandi tegundir. Pá er pað vitað og hefur verið nefnt hér að framan að hagkvæmni í nýtingu næst ekki ef að stofnarnir virða ekki lögsögumörk peirra yfirvalda sem stýra veiðunum. Einnig parf að taka tillit til pess að fiskar éta fiska og hafa einnig önnur tengsl við vistkerfið. Mat á hagkvæmasta afla er pví ekki rétt nema tekið sé tillit til pessara pátta, t.d. með pví að úthluta kvótum fyrir allar tegundir vistkerfisins. Jafnframt parf að taka tillit til pess að ýmis konar notagildi fiskistofna vegna náttúruskoðunar og tilvistar dregur úr vilja til pess að stofnstærðir séu algerlega ákvarðaðar af einkaaðilum.

\section{Lausnir á frjálsu aðgengi}

Pær leiðir sem eru færar til pess að leysa stærstu vandamálin sem fylgja nýtingu endurnýjanlegra náttúruauðlinda með frjálsan aðgang, p.e. óhagkvæmni, ofveiði og offjárfestingu, má flokka í prennt. Í fyrsta lagi geta peir einstaklingar sem hafa aðgengi að auðlindinni og eru að nýta hana komist að samkomulagi um hvernig best sé að haga nýtingunni og stýra henni í sameiningu. Notendurnir sammælast pá um að hefta aðgengi að auðlindinni. Ekki er líklegt að vandinn við frjálsan aðgang leysist á pennan hátt nema um sé аð ræðа auðlind með vel afmarkaða staðsetningu og notendurnir ekki mjög margir. Dæmi gæti verið nokkrir ættbálkar sem búa við sama stöðuvatnið og nýta í pví fiskistofna. Ólíklegra er að pessi lausn komi fram við notkun fiskistofna í sjónum sem ferðast um stór hafsvæði, jafnvel um lögsögu fjölda ríkja. Til eru farsæl dæmi um pað að peir sem hafa aðgang að sameiginlegri auðlind sammælist um skynsamlega nýtingu hennar, í stað pess að falla í pá gryfju að elta eigin skammtímahagsmuni, og án pess að framselja skipulag nýtingarinnar til utanaðkomandi valds. Slík dæmi hafa pað sammerkt að nýting auðlindarinnar skiptir sköpum fyrir afkomu notendanna, peir nýta hana sameiginlega kynslóð eftir kynslóð, heiðarleiki og orðheldni skipta máli par sem einstaklingarnir eru hver öðrum háðir með ýmis samskipti og viðskipti, og pað fyrirkomulag sem viðhaft er við nýtingu auðlindarinnar er sjálfbært (Ostrom (1990)).

Í öðru lagi er hægt að koma á séreignarrétti á auðlindinni með pví að koma henni allri á eina hendi. Pá hefur eigandinn hag af pví að nýta auðlindina á hagkvæman hátt og taka fullt tillit til verðmætis ónýttrar auðlindar par sem ábatinn af henni mun falla eigandanum í skaut. En pá verður hann jafnframt einn um að selja afurðir auðlindarinnar og eins víst að pað hafi í för með sér frekari vandamál. Eigandinn ákveður pá einn hvernig auðlindararðinum er ráðstafað, nema hann sé skattlagður eins og sums staðar er gert par sem um einokunarrekstur er að ræða, til dæmis við olíuvinnslu. Við skattlagningu auðlindararðs flyst ráðstöfunarvaldið yfir honum á hendur stjórnmálamanna. Skattlagningarleiðin hentar vel par sem um einokunarrekstur er að ræða en mun erfiðara er að útfæra hana á samkeppnismarkaði. Í pví tilfelli pyrfti að sérsníða skattlagninguna fyrir hvert fyrirtæki.

Ef um neikvæð ytri áhrif af auðlindanýtingunni er að ræða pá mun nýting á samkeppnismarkaði leiða til of mikillar notkunar og einokunarlausnin par sem einn eigandi 
nýtir auðlindina getur pví verið nær pví sem er best fyrir samfélagið í heild. Pað á til dæmis við ef ekki er tekið tillit til náttúruverndarsjónarmiða við nýtingu auðlindarinnar. Ef pau væru tekin með í reikninginn yrði nýtingin minni en ella. Sama á við ef auðlindin er í einkaeigu einokunarfyrirtækis. Eigandinn hefur pá hag af pví að framleiða minna en gert væri í samkeppni og hegðar sér meira í líkingu við pað sem væri gert ef náttúruverndarsjónarmiðin væru tekin með í reikninginn.

Í priðja lagi eru svo leiðir par sem gripið er til fiskveiðistjórnunar. Pá er yfirvöldum, ríkinu, falið að setja reglur um hver má veiða hvað, hve mikið og hvenær, og framfylgja peim reglum. Umsjón auðlindar parfnast reglna um leyfða notkun, kvaðir, skyldur og réttindi, og par af leiðandi hvað er bannað. Eftirlitsaðferðir, framfylgni og viðurlög eru nauðsynlegir pættir stofnana sem sjá um sameiginlegar auðlindir. Á meðal peirra aðferða við fiskveiðistjórnun sem falla hér undir og voru nefndar hér að framan eru takmarkanir á heildarafla og bann við veiðum pegar leyfðum afla er náð (Homans og Wilen (1997)). Einnig aðgerðir til að draga úr sókn. Par undir falla reglur um veiðarfæri og afmarkanir á veiðitímabilum. Pessar aðgerðir duga jafnan ekki einar sér en peim má engu að síður beita samhliða öðrum aðgerðum (Conrad og Clark (1987)). Takmarkanir á veiðarfærum og lokanir á veiðisvæðum eru einnig markvissar aðgerðir til að vernda til dæmis nýja árganga.

Magnstýring, par sem hámark er sett á leyfðan afla á hverju tímabili, hefur pann kost að ná peim afla sem að er stefnt. Gallinn er sá að magntakmörk á veiðar geta leitt til sóunar par sem ekki er neitt sem tryggir að aflað sé á hagkvæman hátt. Verðstýring, par sem heimild til hverrar aflaeiningar er seld á hverju tímabili eða leigð gegn gjaldi sem endurspeglar réttan jaðarkostnað við veiðarnar hefur pann kost að aflinn verður sóttur á hagkvæman hátt. Aftur á móti er ekki par með sagt að sá afli sem landað er á tímabilinu sé svipaður og að er stefnt.

Segja má að framseljanlegar kvótahlutdeildir séu sambland af stjórn fiskveiða með opinberum afskiptum og úthlutun eignarréttar. Sú leið sameinar kosti magnstýringar og verðstýringar á markaði par sem óvissa ríkir um jaðarábata og jaðarkostnað. Heildarkvóti er settur fyrir hverja tegund og er ákvarðaður fyrir hvert veiðitímabil til að stýra pví magni sem er veitt. Kvótahlutdeildirnar ganga síðan kaupum og sölum og markaðsverðið leiðir til pess að veiðarnar verða hagkvæmar. Kvótakerfi með frjálsu framsali sameinar pví helstu kosti annarra leiða við fiskveiðistjórnun, p.e. að setja efri mörk á aflann og stuðla jafnframt að hagkvæmni í nýtingu.

Að nokkru parf að huga við innleiðingu framseljanlegra kvótahlutdeilda. Par á meðal hvernig útdeilingu kvótahlutdeildanna er háttað í upphafi. Ýmsar leiðir eru færar við pað en aðferðin sem verður fyrir valinu getur haft áhrif á hver fær notið auðlindararðsins, p.e. pess verðmætis sem fiskveiðistjórnunin bjargar frá pví að vera sóað í samkeppni veiðimanna um aflann (Matulich og Sever (1999)). Kvótakerfi með framseljanlegar aflahlutdeildir hafa oft verið innleidd par sem annars konar fiskveiðistjórnunarkerfi, svo sem aðgangstakmarkanir eða dagatakmarkanir haf verið í notkun. Algengast hefur verið að úthluta veiðiheimildum til 
peirra sem eru að stunda veiðarnar pegar kerfið er innleitt (Morgan (1995)). Eitt af pví sem parf að ákveða er hvort kvótahlutdeildirnar eru varanlegar eða hvort peim er úthlutað á ný á hverju ári. Рað skiptir í sjálfu sér ekki miklu máli svo lengi sem viðskipti með pær eru alveg frjáls og pað er mikilvægt að svo sé til að tryggja hagkvæmni. Ef samkeppni á markaðnum er óheft pá myndast verð á kvótahlutdeildunum sem meðal annars endurspeglar varanleika peirra.

Ríkið gæti haldið eign á kvótanum og leigt út kvótahlutdeildir og leigutakinn gæti pá leigt pær áfram. Með pví fyrirkomulagi er ráðstöfunarvaldið yfir arði af kvótanum á hverju ári hjá sitjandi stjórnvöldum. Ríkið gæti líka útdeilt peim í eitt skipti fyrir öll með uppboði og pannig tekið til sín núvirtan arð af kvótanum. Pannig fengju sitjandi stjórnvöld ráðstöfunarrétt yfir öllum kvótaarðinum. Pá er einnig hægt að útdeila kvótahlutdeildum á hvern íbúa og pað mætti jafnvel gera á hverju ári. Með frjálsum viðskiptum hefði par með hver íbúi landsins möguleika á að leysa til sín hlutdeild í arðinum og ráðstafa að vild. Enn önnur aðferð við útdeilingu kvótahlutdeilda pegar kerfi framseljanlegra kvóta er innleitt er að byggja úthlutunina á veiðireynslu. Með peirri aðferð fá peir sem stunduðu veiðar á viðmiðunartímabilinu ráðstöfunarrétt yfir arðinum. Ef meginmarkmiðið með kerfinu er að stuðla að hagkvæmum veiðum skiptir ekki máli hvaða aðferð er beitt við úthlutunina svo framarlega sem viðskipti með hlutdeildirnar eru frjáls. En ef ein leið til úthlutunar varanlegra kvótahlutdeilda hefur verið valin felur hún í sér úthlutun eignarréttar. Hafi eignarréttinum verið úthlutað varanlega er ekki hlaupið að pví að endurúthluta kvótahlutdeildum án pess að bæta eigendunum skaðann.

\section{Stjórn fiskveiða við Ísland}

Fiskveiðistjórnun við Ísland hefur próast á ápekkan hátt og kenningar um fiskveiðistjórnun sem vikið var að hér að framan. Bann við notkun ákveðinna veiðarfæra hafði pekkst um langt skeið, svo sem við lagningu neta í Faxaflóa, notkun botnvörpu og dragnótar. Við útfærslu landhelginnar 1952 var bannað að veiða með botnvörpu og dragnót innan fiskveiðilögsögunnar. Og pegar fiskveiðilögsagan var færð í 200 sjómílur 1976 voru sampykkt ný lög um veiðar í landhelginni með раð markmið að „stuðla að viðgangi og hagkvæmri nýtingu fiskistofna innan íslenskrar fiskveiðilögsögu“. Um petta segir Sigurður Snævarr (1993) að „[p]ótt pannig megi greina verndunarsjónarmið í stjórn fiskveiða á fyrri hluta aldarinnar, virðist fiskveiðistefnan fremur hafa byggst á verndun smábátaútvegs gegn nýjum og stórvirkari veiðarfærum en vernd fiskistofna." (Sigurður Snævarr, 1993, bls. 182).7

Í stuttu máli var ýmislegt reynt við stjórn fiskveiða á seinni hluta síðustu aldar. Oftar en ekki miðaðist fiskveiðistjórnun við ákveðnar tegundir par sem reglur voru innleiddar í kjölfar aflabrests í viðkomandi tegund. Tilraunir með heildaraflakvóta reyndust ekki betur hér við

\footnotetext{
${ }^{7}$ Sjá nánari lýsingu á próun fiskveiðistjórnunar fyrir daga kvótakerfisins í kafla um stjórn fiskveiða í bók Sigurðar Snævarr (1993) og peim heimildum sem par er vísað í.
} 
land en annars staðar. Heildarkvóti einn og sér leiðir til dýrrar samkeppni um hlutdeild í kvótanum. Pegar á reyndi skorti á vilja eða getu til refsinga pegar farið var fram úr heildarkvótanum.

Eftir að horfur um porskveiðar dökknuðu enn haustið 1983 var kvótakerfið lögfest og frá og með árinu 1984 var skipum úthlutað veiðiheimildum par sem botnfisktegundir voru háðar kvóta. Við upphaflega úthlutun var miðað við sögulegan afla áranna 1981 til 1983. Hverju skipi var pannig úthlutað hlutdeild í heildarkvóta í hverri tegund. Í upphafi var kvótakerfið pó langt frá pví að vera hreint kerfi framseljanlegra kvótahlutdeilda. Fyrstu árin var sóknarkvótakerfi rekið samhliða að uppfylltum ákveðnum skilyrðum en sóknarkvótinn takmarkaði daga sem skip gátu verið á botnfiskveiðum. Porskkvóti var svo einnig takmarkaður fyrir skip á sóknarkvóta frá árinu 1988. Sóknarkvótinn var ekki framseljanlegur en almenni kvótinn var pað að uppfylltum skilyrðum. Pannig var framsal kvóta leyft milli skipa sömu útgerðar, innan sömu verstöðvar, milli skipa sem voru ekki innan sömu verstöðvar ef skipt var á mismunandi tegundum á jöfnu verðmæti, eða með sampykki sjávarútvegsráðuneytis að fenginni umsögn sveitarstjórnar og stjórnar sjómannafélags í viðkomandi verstöð er flytja átti afla frá.

Kvótakerfið var endurbætt 1990 og pá var fellt út ákvæði um að lögin væru tímabundin. Eftir pað náði kerfið yfir næstum allar tegundir og öll fiskiskip. Hverju skipi var úthlutað hlutdeild af leyfðum heildarafla hverrar tegundar á hverju fiskveiðiári. Kvóta var úthlutað til smábáta miðað við afla priggja ára á undan. Enn voru pó undanpágur frá kvótanum. Útgerðum báta undir 6 tonnum var leyft að velja í stað aflahlutdeildar að veiða með línu og handfæri með dagatakmörkunum, s.k. krókaleyfi.

Útgerðum var heimilt að flytja aflamark milli skipa sinna, t.d. frá gömlu yfir á nýtt. Aflamarkið fylgdi svo skipunum. Sveitastjórnir höfðu forkaupsrétt á skipi og aflamarki pess ef selja átti skip milli sveitarfélaga. Ef sveitarstjórn ákvað að nýta forkaupsréttinn purfti hún að leita að kaupanda innan sveitarfélagsins. Heimilt var að leigja eða selja aflahlutdeildir. Eins og áður hefur verið bent á er slíkt framsal forsenda pess að fiskveiðistjórnunarkerfið skili hagkvæmum veiðum. Pá var einnig reiknað álag á afla sem fluttur var óunninn úr landi en pað hefur aftur á móti pau áhrif að draga úr hagkvæmni í sjávarútvegi. Eftir breytingarnar á kerfinu 1991 var einnig tekið lágt gjald fyrir veiðileyfi til pess að fjármagna eftirlit með fiskveiðum.

Prátt fyrir nokkra vankanta og fyrirvara var hér í grunninn komið á fiskveiðistjórnunarkerfi með farmseljanlegum aflahlutdeildum. Með slíku kerfi er unnt að stýra heildarafla í hverri tegund innan skekkjumarka og stuðla að pví að veiðar séu stundaðar á hagkvæman hátt, p.e. með lágmarks sóun fyrir samfélagið. En lengi má gott bæta og vel hefði mátt sníða vankantana af lögunum með pví að fækka undanpágum, draga úr brottkasti með auknu eftirliti og viðurlögum, og leita lausna á peim vanda sem fylgir meðafla og líffræðilegu samspili tegunda. 


\section{Gildandi lög og nýtt lagafrumvarp}

Í gildandi lögum um stjórn fiskveiða, lögum nr. 116 2006, segir að markmiðið með peim sé að stuðla að verndun og hagkvæmri nýtingu nytjastofna á Íslandsmiðum. Með pví eigi að tryggja trausta atvinnu og byggð í landinu. Ekki er ljóst af orðalaginu hvort litið er á verndun nytjastofna og hagkvæma nýtingu sem meginmarkmið sem eigi að leiða af sér trausta atvinnu og byggð í landinu, eða hvort traust atvinna og byggð sé meginmarkmið laga um stjórn fiskveiða og verndun og hagkvæm nýting nytjastofna einhvers konar milli markmið. Hvort sem er er ekki skýrt eftir hvaða leiðum verndun nytjastofn eða hagkvæm nýting peirra leiðir til traustrar atvinnu og byggðar.

Kerfið er enn í grunninn kvótakerfi með framseljanlegum aflahlutdeildum. Með tímanum hefur pó ítrekað verið dregið úr hagkvæmni veiða með lagabreytingum. Framsal hefur verið takmarkað og undanpágum fjölgað með línuívilnunum, strandveiðileyfum og byggðakvóta. Allt petta vinnur gegn markmiði laganna um verndun og hagkvæma nýtingu nytjastofna á Íslandsmiðum. Рað blasir við að pessum markmiðum má ná betur með pví að fella allar slíkar undanpágur úr gildi og aflétta öllum takmörkunum á framsali kvóta. Próunin undanfarna tvo áratugi hefur yfirleitt verið í gagnstæða átt og er nýjasta frumvarp ríkisstjórnarinnar sem lagt var fram vorið 2012 engin undantekning frá peirri reglu.

Frekar en að einfalda lögin og gera pau markvissari er lagt til að fjölga peim markmiðum sem stefnt er að með stjórn fiskveiða. Markmið laganna samkvæmt nýju frumvarpi er:

„a. að stuðla að verndun og sjálfbærri nýtingu fiskistofna við Ísland,

b. að stuðla að farsælli samfélagspróun með hagsmuni komandi kynslóða að leiðarljósi,

c. að treysta atvinnu og byggð í landinu,

d. að hámarka pjóðhagslegan ávinning af sjávarauðlindinni og tryggja pjóðinni eðlilega auðlindarentu,

e. að sjávarútvegurinn sé arðsamur og búi við hagstætt og stöðugt rekstrarumhverfi.“

Ekki er hér lengur talað um hagkvæma nýtingu auðlindarinnar og hefur pað markmið verið látið víkja. Höfundar frumvarpsins telja mikilvægara að fiskveiðistjórnun muni stuðla að farsælli samfélagspróun og treysta atvinnu og byggð í landinu. Petta eru miklar byrðar fyrir eina atvinnugrein. Inntakið í lagafrumvarpinu er síðan að draga frekar úr framsali og taka alveg fyrir pað með tímanum. Раð er nokkuð öruggt að með pví mun draga úr hagkvæmni nýtingar fiskistofnanna og ljóst að pað er pví engin tilviljun að pað markmið er fellt brott. Minni hagkvæmni og meiri sóun eru pví líklega meðvituð markmið með boðaðri lagabreytingu. Til að draga frekar úr kostum fiskveiðistjórnunar á kostnað annarra markmiða er lagt til að hluti kvótans verði eyrnamerktur, meðal annars fyrir línuívilnun og til pess að styðja við byggðarlög. Раð kann vel að vera að pað sé æskilegt að stuðla að pví að hluti aflans sé sóttur á tiltölulega óhagkvæman hátt. Рað kann að hafa ýmsa kosti. Pað getur 
líka verið æskilegt af ýmsum ástæðum að sporna gegn pví að fólk flytjist úr tilteknum byggðarlögum í önnur par sem arðsamari vinnu er að fá. Рað getur líka haft ýmsa kosti. En slík markmið eiga tæplega heima í lögum um stjórnun fiskveiða og vinna hreinlega gegn tilgangi pess að hafa yfir höfuð sérstök lög um pá atvinnugrein. Enda er ekkert pví til fyrirstöðu að stuðla að óhagkvæmum veiðum og hvetja fólk til að búa á tilteknum stöðum án pess að slík markmið lendi í mótsögn við fiskveiðistjórnun - jafnvel pótt með stjórnun fiskveiða sé stefnt að hagkvæmri nýtingu fiskistofna. Í kvótakerfi með framseljanlegum aflahlutdeildum gæti hver sem er keypt kvóta. Раð væri einfalt að stofna sjóð í peim tilgangi að niðurgreiða kvótakaup fyrir smábáta eða til að niðurgreiða kvótakaup ákveðinna byggðarlaga ef vilji er til pess að fólk búi par og starfi við fiskveiðar. Kosturinn við slíkt kerfi er að pað kemur ekki niður á hagkvæmni fiskveiða að öðru leyti, p.e. sóun við almennar veiðar væri lágmörkuð og kostir kvótakerfis með framseljanlegar aflahlutdeildir nýttust til fulls. Og kostnaðurinn við smábátaútgerð og byggðastefnu sem tengd er fiskveiðum væri uppi á borðinu.

\section{Umræður}

Rökin fyrir ávinningi af vel útfærðri fiskveiðistjórnun eru sterk. Með pví að stuðla að hagkvæmri nýtingu fiskistofna með stjórnun fiskveiða skapast mikil verðmæti umfram pau sem verða til ef ekki er til staðar slíkt fiskveiðistjórnunarkerfi. Pær breytingar sem leiða til hagkvæmari veiða fela í sér breytingu á skipulagi og aðferðum við veiðar og vinnslu á sambærilegan hátt og hagræðing í allri framleiðslu leiðir til breytinga. Rétt eins og framfarir í landbúnaði á liðinni öld voru vinnusparandi pá eru framfarir í sjávarútvegi pað einnig. pegar miklar breytingar verða á skipulagi fiskveiða verða breytingar á próun byggða. Раð gerðist líka pegar miklar breytingar urðu á vinnulagi við landbúnað.

Eitt form byggðastefnu felst í pví að sporna við breytingum og viðhalda byggð á tilteknum svæðum sem líkastri pví sem varð á meðan atvinnuskipting var með öðrum hætti en nú er. Áhrifarík leið til að reka slíka byggðastefnu er að berjast gegn peim breytingum sem leiða af sér breytingar í byggðapróun, hvort sem pær má rekja til framfara í landbúnaði, sjávarútvegi eða öðrum greinum. Pví miður ber pað frumvarp til laga um stjórn fiskveiða sem lagt var fram á pingi vorið 2012 pess merki að reynt er að draga úr skilvirkni kvótakerfisins og hvetja með markvissum hætti til óhagkvæmra fiskveiða, sennilega í peim tilgangi að stöðva pá breytingu á próun byggða sem hlýst af hagkvæmara fiskveiðistjórnunarkerfi. Til að mynda er stefnt að pví að fella með tímanum niður heimild til framsals aflahlutdeilda (12. gr.) en slíkt framsal er forsenda pess að kvótakerfið leiði til hagkvæmra fiskveiða. Pá er kveðið á um forgang ráðherra til aflahlutdeilda í peim tilgangi að sporna gegna atvinnu- og byggðapróun (13. gr.).

Раð er ekkert rangt við að reka byggðastefnu ef almennur vilji er fyrir pví en pað er ástæðulaust að láta pað bitna á frampróun og hagkvæmni tiltekinna atvinnugreina. Að ætla sjávarútvegi að taka á sig kostnaðinn við byggðastefnuna er í besta falli ípyngjandi fyrir 
greinina. Með slíku „fiskveiðistjórnunarkerfi“ er ekki verið að leysa vandamál tengd auðlindanýtingu heldur er verið að nota fiskveiðistjórnun til pess að láta sjávarútveginn axla kostnaðinn við að „leysa“ önnur vandamál um hríð. Раð er hugsanlegt að slíkar breytingar séu gerðar að vandlega hugsuðu máli en pað er líka hugsanlegt að pær séu settar fram í peim tilgangi að höfða til sjónarmiða ákveðinna hópa kjósenda.

Pær breytingar sem lagðar eru til í frumvarpi til laga um stjórn fiskveiða sem lagt var fram vorið 2012 eru til pess fallnar að draga úr hagkvæmni fiskveiða og verðmætasköpun í pessari mikilvægu grein. Breytingar sem hvetja til sóunar og hefta hagkvæmni munu að öllum líkindum leiða til minni hagvaxtar og kaupmáttar en ella. Pessar hugmyndir fela í sér ákveðið afturhvarf frá skilvirkri fiskveiðistjórnun. En pað er ekki útilokað að slíkt sé gert til að mæta vilja pjóðarinnar. Ekki er allt unnið með pví að einblína á arðsemi og hámarks vellíðan pjóðarinnar er ekki endilega tryggð með pví að nýta allar auðlindir á sem hagkvæmastan hátt. Skipting teknanna skiptir pjóðina einnig máli og ekki er sama hver metur pað hvernig eigi að vega vellíðan einstaklinganna saman til pess að fá út vellíðan pjóðarinnar. Раð er einfaldlega ekki til neitt eitt rétt svar við pví hvernig hámarka beri vellíðan alls samfélagsins. Með öðrum orðum pá er vel hugsanlegt að pað sé vilji pjóðarinnar að fá minni köku og skipta henni á jafnari hátt. Ef pannig er í pottinn búið eru pær breytingar sem lagt er upp með í nýju lagafrumvarpi um stjórn fiskveiða kannski skiljanlegri en ef gengið er út frá hámörkun arðsemi sem markmiði fiskveiðistjórnunar.

Hér að framan var pað nefnt að lítil samfélög gætu leyst í samvinnu úr peim vanda sem fylgir frjálsu aðgengi að sameiginlegri auðlind (Ostrom (1990)). Markmið um „sanngjarna“ skiptingu auðlindararðsins vega pá gjarnan pyngra en markmið um hagkvæma nýtingu. Í stærri samfélögum par sem auðlindararðurinn er tiltölulega lítill reiknað á hvern mann er aftur tilhneiging til að stuðla að verndun og auka hagkvæmni nýtingar með lagasetningu eða skilgreiningu eignarréttar. •að fiskveiðistjórnunarkerfi sem próaðist hér á landi á árunum frá 1984 og fram yfir 1990 stefndi í pá átt að ná hámarks hagkvæmni í sjávarútvegi. Breytingar á lögum um fiskveiðistjórnun hafa á síðustu árum gengið í öfuga átt, p.e. dregið hefur úr mikilvægi hagkvæmra veiða og meira verið lagt upp úr að vernda óhagkvæmar veiðiaðferðir (krókaleyfi, línuívilnun, strandveiðar og takmörkun farmsals) og viðhalda veiðum og vinnslu í peim bæjarfélögum sem pær atvinnugreinar hafa vegið pungt (forgangsréttur, takmörkun framsals, álag á útfluttan afla). Мeð nýju lagafrumvarpi er enn stefnt að pví að draga úr hagkvæmni veiðanna og áherslan virðist meðal annars snúa að endurúthlutun kvótahlutdeilda. Hugsanlegt er að par sem samfélagið er frekar lítið og arður af fiskveiðum mögulega mikill (einkum ef pær eru stundaðar á hagkvæman hátt) pá hafi skipting arðsins hlotið hærra vægi í samfélaginu með tímanum. Раð gæti skýrt vilja stjórnmálamanna til pess að mæla fyrir lagabreytingum sem draga úr hagkvæmni veiðanna en stjórnast af öðru eins og til dæmis byggðarsjónarmiðum, án pess að kostnaðinum við pað sé hleypt upp á yfirborðið. Önnur skýring á pessari próun gæti verið aukið vægi 
samfélagslegra sjónarmiða, svo sem að tryggja lágmarks fjölda atvinnu við fiskveiðar, á kostnað hagkvæmni við veiðarnar (Péreau, Doyen, Little og Thébaud (2012)).

\section{Heimildir}

Anderson, Lee G. (1994). „An economic analysis of highgrading in ITQ fisheries regulation programs" Marine Research Economics, 9, bls. 209-226.

Árnason, Ragnar (1994). „On catch discarding in fisheries“ Marine Resource Economics, 9, bls. 189-207.

Brown, Gardner M. (2000). „Renewable natural resource management and use without markets", Journal of Economic Literature, 38, bls. 875-914.

Conrad, Jon M. og Colin W. Clark (1987). Natural resource econmics. Cambridge.

Davies, R.W.D., S.J. Cripps, A. Nickson og G. Porter (2009). „Defining and estimating global marine fisheries bycatch" Marine Policy, 33, bls. 661-672.

Frumvarp til laga um stjórn fiskveiða. Pingskjal 1052 - 657. mál. Alpingi, 2011-2012.

Gordon, H. Scott (1954). "The economic theory of a common-property resource: the fishery" The Journal of Political Economy, 62 (2), bls. 124-142.

Hagfræðistofnun (2007). Hlutur sjávarútvegs í pjóðabúskapnum: skýrsla til Landssambands íslenskra útvegsmanna, no. C07:05.

Hardin, Garrett (1968). „The tragedy of the commons“, Science, vol. 162, bls. 1243-1248.

Homans, Frances R. og James E. Wilen (1997). „A model of regulated open access resource use" Journal of Environmental Economics and Management, 32, bls. 1-21. Academic Press.

Lög nr. 116 2006. Lagasafn (útgáfa 140a). Alpingi.

Lög nr. 74 2012. Lagasafn (útgáfa 140b). Alpingi.

Matulic, Scott C. og Murat Sever (1999). „Reconsidering the initial allocation of ITQs: the search for a Pareto-safe allocation between fishing and processing sectors" Land Economics, 75, bls. 203-219.

Morgan, G. R. (1995). „Optimal fisheries quota allocation under a transferable quota (TQ) management system“ Marine Policy, 19 (5), bls. 379-390. Elsevier.

Ostrom, Elinor (1990). Governing the commons: the evolution of institutions for collective actions. Cambridge. 
Péreau, Jean-Christophe, Luc Doyen, Rich Little og Olivier Thébaud (2012). „The tripple bottom line: meeting ecological, economic and social goals with individual transferable quotas" Journal of Environmental Economics and Management, 63, bls. 419-434.

Schaefer, Milner B. (1954). "Some aspects of the dynamics of populations important to the management of the commercial marine fisheries", Inter-American tropical tuna commission, vol. 1, no. 2. La Jolla, California.

Sigurður Snævarr (1993). Haglýsing Íslands. Heimskringla. 